University of Nebraska - Lincoln

DigitalCommons@University of Nebraska - Lincoln

USDA National Wildlife Research Center - Staff Publications
U.S. Department of Agriculture: Animal and Plant Health Inspection Service

March 1995

\title{
Foraging Behaviors of Snowy Egrets (Egretta thula) and Yellow- crowned Night-Herons (Nyctanassa violacea) in South Louisiana
}

\author{
D. Tommy King \\ USDA/APHIS/WS National Wildlife Research Center, tommy.king@aphis.usda.gov \\ Dwight LeBlanc \\ USDA/APHIS, Animal Damage Control
}

Follow this and additional works at: https://digitalcommons.unl.edu/icwdm_usdanwrc

Part of the Environmental Sciences Commons

King, D. Tommy and LeBlanc, Dwight, "Foraging Behaviors of Snowy Egrets (Egretta thula) and Yellowcrowned Night-Herons (Nyctanassa violacea) in South Louisiana" (1995). USDA National Wildlife Research Center - Staff Publications. 545.

https://digitalcommons.unl.edu/icwdm_usdanwrc/545

This Article is brought to you for free and open access by the U.S. Department of Agriculture: Animal and Plant Health Inspection Service at DigitalCommons@University of Nebraska - Lincoln. It has been accepted for inclusion in USDA National Wildlife Research Center - Staff Publications by an authorized administrator of DigitalCommons@University of Nebraska - Lincoln. 


\title{
Foraging Behaviors of Snowy Egrets (Egretta thula) and Yellow-crowned Night-Herons (Nyctanassa violacea) in South Louisiana
}

\author{
D. TOMmY KING ${ }^{1}$ AND DWight LeBlanC ${ }^{2}$ \\ ${ }^{1}$ USDA/APHIS, Animal Damage Control, Denver Wildlife Research Center \\ Mississippi Research Station, P. O. Drawer 6099 \\ Mississippi State University, MS 39762 USA \\ ${ }^{2}$ USDA/APHIS, Animal Damage Control \\ P. O. Box 589 \\ Port Allen, LA 70767 USA
}

\begin{abstract}
We report two previously undescribed foraging techniques used by Snowy Egrets (Egretta thula) and Yellow-crowned Night-Herons (Nyctanassa violacea) to catch crawfish (Procambarus spp.). Snowy Egrets were selecting crawfish that had recently molted their shells and Yellow-crowned Night-Herons were targeting crawfish that were emerging from their burrows. These observations were conducted on commercial crawfish ponds near Catahoula, LA, USA. Received 2 June 1995, accepted 14 August 1995.
\end{abstract}

Key Words.-Commercial crawfish pond, Crawfish, Egretta thula, Foraging, Nyctanassa violacea, Procambarus spp., South Louisiana, Snowy Egret, Yellow-crowned Night-Heron.

Colonial Waterbirds 18(2):224-225, 1995

Many foraging behaviors of Snowy Egrets (Egretta thula) and Yellow-crowned Night-Herons (Nyctanassa violacea) are well documented in the literature (Meyerriecks 1962; Rogers 1974, 1983; Kushlan 1976, 1978; Riegner 1982, 1983; Niethammer and Kaiser 1983; Hancock and Kushlan 1984). Snowy Egrets are best described as having a diverse foraging repertoire (Hancock and Kushlan 1984), while Yellow-crowned Night-Herons are considered by many to be crustacean specialists (Riegner 1982, 1983; Niethammer and Kaiser 1983; Hancock and Kushlan 1984; Martin and Hamilton 1985). Both species commonly use "stand and wait" and "slowly walking" techniques while foraging (Rogers 1983, Hancock and Kushlan 1984).

On 19 May 1994 near the town of Catahoula $\left(30^{\circ} 10^{\prime} \mathrm{N}, 91^{\circ} 40^{\prime} \mathrm{W}\right)$, in St. Martin Parish, Louisiana we encountered large numbers of wading birds foraging in two commercial crawfish (Procambarus spp.) ponds $(1 \times 0.8 \mathrm{~km})$ which were being drained so that the crawfish would burrow and reproduce. We observed two previously undescribed foraging techniques being used by Snowy Egrets and Yellow-crowned Night-Herons to catch crawfish.
A group of 11 Snowy Egrets was observed "walking slowly" toward us as they foraged in the shallow water of a borrow ditch. These egrets were observed from distances of 2-50 $\mathrm{m}$ with $10 \times 50 \mathrm{~mm}$ binoculars on a clear morning from 08:45-10:00 CST. From our vantage point, it appeared that each egret would occasionally catch a prey item in the water with a bill thrust, manipulate it by opening and closing its bill two or three times, and either drop or swallow it before resuming "walking slowly" toward us. As the egrets moved closer, we observed that the primary prey was crawfish.

It appeared to us that manipulation of the prey in the egrets' bill was used to test for hardness and select the most palatable items. The carapaces of dropped crawfish appeared to be hard. Crawfish that were swallowed hung limply during bill manipulation, apparently because these crawfish had recently molted. Presumably, these soft-shelled crawfish were easier to swallow than their hard-shelled counterparts. As the Snowy Egrets moved past us, we noted that all 11 were using this shell testing technique when crawfish were caught. Interestingly, fish were not manipulated in this manner; all fish were swallowed immediately. 
Throughout the same day, we observed approximately $400 \quad$ Yellow-crowned Night-Herons evenly distributed over the mud surface of an adjacent crawfish pond which had been drained of most of its water a few days earlier. The only standing water was in borrow ditches on two sides of the pond. These night-herons were spaced about $10 \mathrm{~m}$ apart, and all were in "stand and wait" postures facing the sun. We observed birds striking at prey in front of them and either swallowing or resuming "stand and wait" postures. After a night-heron swallowed its prey, or if a capture attempt did not occur within approximately $10 \mathrm{~min}$, the bird would run forward several meters, stop, and resume a "stand and wait" posture. This pattern was repeated by each night-heron as they moved across the pond bottom. Closer observations, from $10-40 \mathrm{~m}$ with $10 \times 50 \mathrm{~mm}$ binoculars, showed that the night-herons were standing in front of the entrances to crawfish burrows, with their shadows cast behind them rather than over the burrow entrance. Crawfish emerging from burrows were captured and swallowed. The foraging birds then would move to the next burrow entrance, always maintaining the $10 \mathrm{~m}$ buffer between themselves and other foraging night-herons. No intraspecific aggression between adjacent night-herons was observed. The night-herons moved west to east in the morning and east to west in the afternoon, always facing the sun.

\section{ACKNOWLEDGMENTS}

We thank the people of Clearwater Cajun Fisheries for their hospitality and allowing us access to their facility. We also thank E. Hill, D. Mott and J. Glahn for providing helpful comments on this manuscript.

\section{LITERATURE CITED}

Hancock, J. and J. A. Kushlan. 1984. The herons handbook. Harper and Row, New York.

Kushlan, J. A. 1976. Feeding behavior of North American herons. Auk 93:86-94.

Kushlan, J. A. 1978. Feeding ecology of wading birds. Pages 249-297 in Wading Birds (A. Sprunt IV, J. C. Ogden, and S. Winckler, Eds.). Research Report No. 7. National Audubon Society. New York.

Martin, R. P. and R. B. Hamilton. 1985. Wading bird predation in crawfish ponds. Louisiana Agriculture 28:3-5.

Meyerriecks, A. J. 1962. Diversity typifies heron feeding. Natural History 71:48-59.

Niethammer, K. R. and M. S. Kaiser. 1983. Late summer food habits of three heron species in northeastern Louisiana. Colonial Waterbirds 6:148-153.

Riegner, M. F. 1982. The diet of Yellow-crowned Night-Herons in the eastern and southern United States. Colonial Waterbirds 5:173-176.

Riegner, M. F. 1983. Foraging behavior of Yellow-crowned Night-Herons in relation to behavior, distribution, and abundance of prey. Colonial Waterbirds 6:71.

Rogers, J. A., Jr. 1974. Aerial feeding by Snowy and Great Egrets in Louisiana waters. Wilson Bulletin 86:70-71.

Rogers, J. A., Jr. 1983. Foraging behavior of seven species of herons in Tampa Bay, Florida. Colonial Waterbirds 6:11-23. 